\title{
ВПЛИВ ФАКТОРІВ ПОЄДНАННЯ ПОРІД ТА ТРИВАЛОСТІ ПІДСИСНОГО ПЕРІОДУ НА ВІДТВОРЮВАЛЬНІ ЯКОСТІ СВИНОМАТОК
}

\author{
Швачка Руслан Петрович \\ аспірант \\ Сумський національний аграрний університет \\ ORCID: 0000-0001-7185-4343 \\ E-mail: ruslans19hvachka@gmail.com
}

Повод Микола Григорович

доктор сільськогосподарських наук, професор

Сумський національний аграрний університет

ORCID: 0000-0001-9272-9672

E-mail: nic.pov@ukr.net.

В умовах ТОВ «НВП «Глобинський свинокомплекс» досліджували вплив варіантів породних поєднань свиноматок та тривалості підсисного періоду на їх відтворювальні якості. Було ссрормовано 2 технологічні групи свиноматок зі звичайним (28 діб) та скороченим (21 діб) терміном підсисного періоду. Кожну з отриманих груп поділили з врахуванням генетичної належності на контрольну (ЛㅜВБЗ) та дослідну (ВБㅇЛ $)$. Встановлено, що кращий показник багатоплідності спостерігався у тварин з варіантом породного поєднання ЛфхВБҺ, при скороченій тривалості

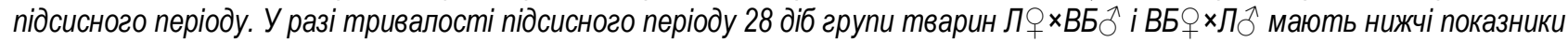
на 0,08 та 0,16 голови відповідно. Співвідношення статей у всіх досліджуваних групах знаходилося практично на одному рівні з коливання в бік кнуриів (50,33-50,84 \%). Найбільша маса гнізда при народженні спостерігалася у тварин групи

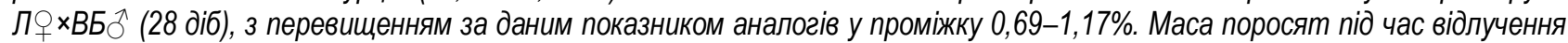
коливалася у проміжку 5,42-7,73 ке. При цьому спостерігається перевага груп з більшою тривалістю підсисного періоду. Найкращий показник середньодобового приросту поросят спостерігався у твварин групи ВБо хЛ Оิ (28 діб) на рівні 235,05

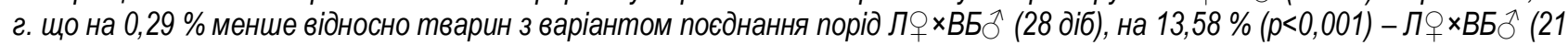

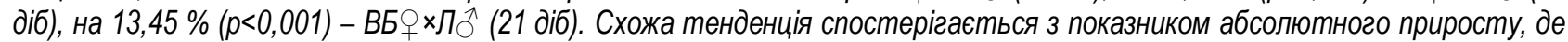
найбільше значення мають тварини дослідної групи із традиційною тривалістю підсисного періоду ВБО хЛ Зิ на рівні 6,35 ке, а найменшу тварини групи Ло×ВБへ (21 діб) - 4,06 ке. Найбільшу кількість поросят відлучали у свиноматок 3 варіантом породного поєднання Ло ×ВБ今, зі скороченим терміном підсисного періоду. Найкраща збереженість

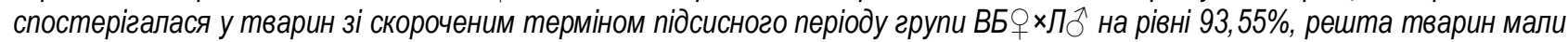
нижчі показники у проміжку 0,03-2,93\%. Встановлено, що фрактор варіанту поєднання породи не впливає на показники: кількості поросят при народженні, кількості поросят при відлученні, збереженість та маси гнізда поросят на період відлучення. Водночас знайдено статистично значний вплив тривалості підсисного періоду на масу гнізда поросят під час відлучення на рівні 67,81\%. За комплексною оцінкою відтворювальних якостей між групами тварин не виявлено суттєєвої відмінності за даним показником (різниия знаходилася в проміжку 0,08 - 0,3 бала). nopid.

Ключові слова: свиноматка, поросята, підсисний період, приріст, багатоплідність, збереженість, поєднання

DOI: https://doi.org/10.32845/bsnau.lvst.2020.1.14

Провідні компанії по виробництву свинини ставлять за мету підвищення генетичного потенціалу тварин. Для цього проводиться селекція тварин за відтворювальними та відгодівельними якостями $[4,7,11]$.

У збільшенні виробництва м'ясної свинини на території України особлива роль відводиться породам ландрас та велика біла, які вирізняються цінним материнськими якостями i широко використовується в промисловому свинарстві в різних варіантах промислового схрещування та гібридизації [12].

За даними досліджень Баркаря $€$. В. та його колег [1], при отриманні для відгодівлі помісних тварин поєднань велика білахландрас та велика білахп'єтрен спостерігається скорочення віку досягнення живої маси 100 кг та підвищується показник середньодобових приростів. Разом 3 тим, схрещування двопородних гібридів порід ЛхВБ (ландрасхвелика біла) з кнуром породи пєтрен [6] показали, що продуктивність у них була вища ніж у чистопородних маток, які схрещувалися з кнурами породи ландрас.
При дослідженні поєднання порід ВБ×ВБ (велика білахвелика біла) та ВБхЛ (велика білахландрас) Федоренкова Л. А. [13] дійшла висновку про відсутність вірогідної різниці між ними за показниками багатоплідності та молочності, а при поєднанні свиноматок ВБ з кнурами породи дюрок спостерігалося вирогідне зниження багатоплідність до 9,6 голови, а молочності - 48,6 кг. При використанні чистопородних свиноматок великої білої породи спостерігаються гірші показники за середньодобовими приростами у поросят протягом підсисно-відгодівельного періоду відносно тварин 3 використання поєднань схрещування ВБхЛ, зазначає Пелих B. Г. [8].

За результатами промислового схрещування великої білої породи 3 кнурами - порід йоркширської, ландрас і дюрок, Максимов А. Г. та Петренко М. О. [5, 9] дійшли висновку, що найбільш ефективним в плані підвищення у помісей забійних показників і якості м'яса виявилося поєднання свиноматок великої білої породи з кнурами- 
плідниками породи ландрас. Згідно досліджень Березовського М. Д. [3] використання двопородного

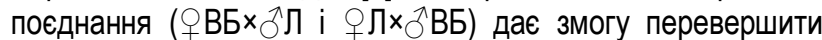
чистопородну велику біла за кількістю поросят за опорос на 0,6 -0,9 голови, але при цьому спостерігається відставання від чистопородних ландрасів (0,4-0,7 голови поросят). На думку Повода М. Г. [10] при схрещуванні природних поєднань ВБхЛ з кнурами спеціалізованої синтетичної лінії Max Gro ірландської селекції спостерігаються кращі показники відтворювальної продуктивності в порівнянні з їх аналогами української селекції, при цьому не знайдено суттєвих відмінностей за інтенсивністю росту поросят в підсисний період в гніздах різного походження.

Окрім генотипових фракторів на продуктивність свиноматок мають суттєвий вплив паратипові фрактори одним з яких $є$ тривалість підсисного періоду. В країнах Північної та Південної Америки, Азії та Австралії останнім часом, з метою інтенсифікації використання свиноматок, практикують раннє в 16-21 добу відлучення поросят від свиноматки [14, 15]. Але різні генотипові поєднання свиноматок неоднаково реагують на фракт такого відлучення. В доступній літературі недостатньо відображено залежність відтворювальних якостей свиноматок різного походження від тривалості підсисного періоду, особливо в жорстких умовах степу України. Тому метою наших досліджень було порівняння відтворювальної продуктивності свиноматок основних материнських порід свиней - великої білої та ландрас, як за прямого так і реципрокного схрещування у системі гібридизації в умовах промислового свинокомплексу степової зони України за різної тривалості підсисного періоду та впливу цих факторів на основні відтворні показники свиноматок.

Матеріали та методи досліджень. В умовах ТОВ «НВП «Глобинський свинокомплекс» за принципом груп аналогів було сфрормовано 3 врахуванням генетичної належності $(Л \bigcirc \times$ ВБ $)$ та $($ ВБ $\bigcirc \times Л \hat{)} 2$ групи свиноматок по 270 голів кожна, перша з яких була контрольною, а друга дослідною (табл. 1). Осіменяли тварин обох поєднань змішаною спермою одних і тих же кнурів синтетичної лінії Max Gro. У половини свиноматок кожної групи термін підсисного періоду складав 28 діб, а у половини він мав 21 добу. Тварини утримувалися за ідентичних умов як в період поросності так і в період лактації.

Схема досліду

\begin{tabular}{|c|c|c|c|c|}
\hline \multirow{3}{*}{$\begin{array}{l}\text { Група свиноматок } \\
\text { Породні поєднання свиноматок } \\
\text { Генотип кнурів }\end{array}$} & \multirow{2}{*}{\multicolumn{2}{|c|}{$\frac{\text { ( (контрольна) }}{\text { ЛО ×ВБ今 }}$}} & \multirow{2}{*}{\multicolumn{2}{|c|}{$\frac{\text { II (дослідна) }}{\text { ВБО } \times Л \overbrace{}^{\wedge}}$}} \\
\hline & & & & \\
\hline & Max Gro & Max Gro & Max Gro & Max Gro \\
\hline Середня тривалість підсисного періоду, діб & 28 & 21 & 28 & 21 \\
\hline Кількість опоросів & 135 & 135 & 135 & 135 \\
\hline
\end{tabular}

Примітки: Л - порода ландрас ірландського походження; ВБ - велика біла порода ірландського походження.

Годівля свиноматок була повноцінною та збалансованою, комбікормами відповідних рецептур, які виготовлялись на власному комбікормовому заводі. Підгодівля поросят обох груп здійснювалась 37 доби життя престартерними кормами компанії Cargil. Досліджувалися наступні показники: кількість поросят при народженні, багатоплідність, розподіл поросят у гнізді за статевою ознакою, маса гнізда при народженні, великоплідність, збереженість поросят та середньодобовий приріст.

Для визначення комплексної оцінки відтворювальних якостей досліджуваних тварин використали оціночний індекс за обмеженою кількістю ознак [2].

$$
\boldsymbol{I}=\boldsymbol{B}+2 \boldsymbol{W}+35 \boldsymbol{G}
$$

де: I - індекс відтворювальних якостей, балів;

В - кількість поросят при народженні, гол.;

W - кількість відлучених поросят, гол.;

G - середньодобовий приріст поросят при відлученні,

Кг.

Шляхом двофракторного дисперсійного аналізу визначали силу впливу генетичного поєднання материнських порід та тривалості підсисного періоду на зміни основних показників відтворювальних якостей свиноматок.

Результати досліджень. 3 а результатами дослідження (табл. 2) встановлено, що за загальною кількістю поросят при народженні між породними поєднаннями свиноматок суттєвої розбіжності не встановлено, простежувалась тенденція до підвищення на 0,11 голови або $0,75 \%$ у поєднанні Л показника в порівнянні 3 дослідною групою. Також встановлена тенденція до збільшення багатоплідність на 0,08 голови або 0,59\% у тварин контрольної групи відносно дослідної. Суттєвої різниці між кількістю кнурців та свинок у гніздах обох груп не виявлено. У свиноматок контрольної групи також встановлена тенденція до підвищення на 0,18 кг, або на 0,96\% маси гнізда поросят при народженні порівняно 3 дослідною. За кількістю поросят під час відлучення та їх індивідуальною масою та масою гнізда поросят суттєвої різниці не встановлено, тоді, як вища на 1,2\%, збереженість спостерігалася у тварин дослідної групи в порівнянні з контрольною. За показниками інтенсивності росту також не встановлено суттєвої різниці між свиноматками обох груп.

За оціночним індексом свиноматки дослідної групи мали незначну перевагу за даним показником на 0,08 бала, або 0,17 \% відносно їх аналогів контрольної групи.

У процесі дослідження породних поєднань зі скороченим терміном відлучення середня кількість поросят під час народження була вищою у тварин контрольної групи на 0,05 голови, або 0,34\% відносно дослідної. Тварини варіанта породного поєднання Л $凵$ ×ББ $\widehat{\jmath}$ мали тенденцію до покращення показника багатоплідності на 0,29\% у порівнянні $з$ їх аналогами в дослідній групі. Різниця між масою гнізда під час народження варіантів породних поєднань знаходиться на рівні 0,01 кг, що не містить суттєвої різниці за даним показником. При тривалості підсисного періоду в 21 добу вища кількість поросят під час відлучення спостерігалася у тварин контрольної групи на 0,01 голови, або 0,08\% у порівнянні 3 дослідною. Краща збереженість спостерігалася у свиноматок дослідної групи та становила 93,55\%, що на 0,03\% більше контрольної. 
Спостерігалася незначна перевага середньої маси одного поросяти під час відлучення у свиноматок з варіантом поєднання порід ВБ $\odot \times Л \widehat{~}$ поросят під час відлучення дослідної групи знаходилася на рівні 68,80 кг, що на 0,95 \% більше у порівнянні з даним показником контрольної групи. Середньодобові прирости дослідної групи становили 203,44 г, що на 0,16 \% вище за дані показники контрольної. Абсолютний приріст дослідної групи знаходиться на рівні 4,07 кг, що на 0,01 кг більший у порівнянні 3 контрольною групою. Тварини контрольної групи мали кращі показники відносного приросту на 0,05 \%, або 0,04 \% відносно тварин з варіантом поєднання порід

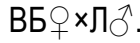

Залежність відтворювальних якостей свиноматок від породних поєднань та терміну підсисного періоду

\begin{tabular}{|c|c|c|c|c|}
\hline Група свиноматок & \multirow{2}{*}{\multicolumn{2}{|c|}{$\begin{array}{l}\text { I (контрольна) } \\
\text { Л } 9 \text { ×ББ } \\
\end{array}$}} & \multirow{2}{*}{\multicolumn{2}{|c|}{$\frac{\text { ІІ (дослідна) }}{\text { ВБО } \times Л \hat{O}^{\lambda}}$}} \\
\hline Породні поєднання свиноматок & & & & \\
\hline Середня тривалість підсисного періоду, діб. & 28 & 21 & 28 & 21 \\
\hline Всього народилося поросят, гол. & $14,64 \pm 0,126$ & $14,63 \pm 0,127$ & $14,53 \pm 0,131$ & $14,58 \pm 0,125$ \\
\hline Багатоплідність, гол. & $13,61 \pm 0,107$ & $13,69 \pm 0,119$ & $13,53 \pm 0,120$ & $13,65 \pm 0,110$ \\
\hline Кнурці, гол. & $6,89 \pm 0,058$ & $6,94 \pm 0,085$ & $6,81 \pm 0,063$ & $6,94 \pm 0,078$ \\
\hline Свинки, гол. & $6,72 \pm 0,058$ & $6,75 \pm 0,047$ & $6,72 \pm 0,068$ & $6,71 \pm 0,438$ \\
\hline Маса гнізда поросят при народженні, кг & $18,81 \pm 0,165$ & $18,60 \pm 0,153$ & $18,63 \pm 0,156$ & $18,59 \pm 0,142$ \\
\hline Великоплідність, кг & $1,38 \pm 0,005$ & $1,36 \pm 0,003$ & $1,38 \pm 0,003$ & $1,36 \pm 0,003$ \\
\hline Кількість поросят при відлученні, гол. & $12,25 \pm 0,080$ & $12,67 \pm 0,064$ & $12,33 \pm 0,085$ & $12,66 \pm 0,063$ \\
\hline Збереженість, \%. & $90,81 \pm 0,511$ & $93,52 \pm 0,480$ & $92,01 \pm 0,526$ & $93,55 \pm 0,440$ \\
\hline Маса одного поросяти при відлученні , кг. & $7,71 \pm 0,009$ & $5,42 \pm 0,009$ & $7,73 \pm 0,010$ & $5,43 \pm 0,009$ \\
\hline Маса гнізда поросят при відлученні, кг. & $94,47 \pm 0,625$ & $68,71 \pm 0,364$ & $95,24 \pm 0,667$ & $68,80 \pm 0,370$ \\
\hline Приріст живої маси поросят: & & & & \\
\hline середньодобовий, г. & $234,38 \pm 0,396$ & $203,12 \pm 0,51$ & $235,05 \pm 0,390$ & $203,44 \pm 0,495$ \\
\hline абсолютний, кг. & $6,33 \pm 0,011$ & $4,06 \pm 0,010$ & $6,35 \pm 0,184$ & $4,07 \pm 0,010$ \\
\hline відносний, \%. & $139,26 \pm 0,236$ & $119,72 \pm 0,193$ & $139,41 \pm 0,094$ & $119,67 \pm 0,171$ \\
\hline Оціночний індекс, балів. & 46,31 & 46,14 & 46,39 & 46,09 \\
\hline
\end{tabular}

За показниками комплексного оцінювання свиноматок за індексом М.Д. Березовського встановлено, що свиноматки контрольної групи мали на 0,05 більшу кількість балів у порівнянні з дослідною.

3 усіх піддослідних груп тварин краща багатоплідність спостерігалася у тварин контрольної групи

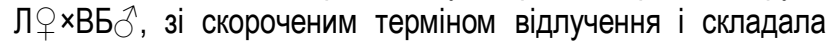
13,69 голови, що на 0,04 голови більше порівняно з ії аналогом за тривалістю підсисного періоду групи ВБ $\odot \times Л \widehat{~}$ При тривалості підсисного періоду 28 діб групи тварин

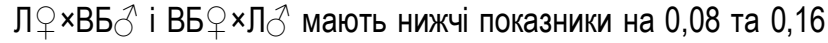
голови відповідно.

Співвідношення статей у всіх досліджуваних групах знаходилося практично, а одному рівні 3 коливання в бік кнурців у проміжку 50,33 \% -50,84\%. Найбільша маса гнізда при народженні спостерігалася у тварин 3 варіантом поєднання порід Л $\bigcirc \times$ ВБ $\hat{\circ}$ (28 діб), що на 0,96 \% менше у порівнянні з тваринами групи ВБО хЛ $\widehat{\jmath}(28$ діб), на 1,12\% Л으두 (21 діб), на 1,17 \% для тварин 3 варіантом поєднання порід ВБ відлучення коливалася у проміжку 5,42 - 7,73 кг, при цьому спостерігається перевага груп 3 більшою тривалістю підсисного періоду. У групи свиноматок ВБ $\odot$ хл ${ }^{\lambda}$ (28 діб) маса гнізда при відлученні знаходиться на рівні 95,24 кг, що

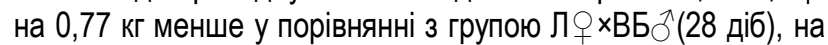

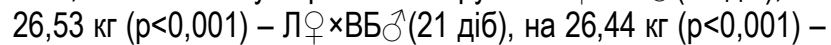
ВБ $\odot \times л \overbrace{}^{\lambda}(21$ діб).
Найкращий показник середньодобового приросту поросят спостерігався у тварин групи ВБ + хлð (28 діб) на рівні 235,05 г. що на 0,29\% менше відносно тварин 3 варіантом поєднання порід лфхВБ今 (28 діб), на 13,58\% $(p<0,001)$ - ЛохВБЛ (21 діб), на $13,45 \% \quad(p<0,001)-$ ВБ $\odot \times Л \bigcirc^{\lambda}(21$ діб).

Схожа тенденція спостерігається 3 показником абсолютного приросту, де найбільше значення мають тварини дослідної групи зі традиційною тривалістю підсисного періоду ВБ $\odot$ хлð на рівні 6,35 кг, а найменшу тварини групи Л $\odot$ ×ББ $\widehat{~(21 ~ д і б) ~-~ 4,06 ~ к г . ~ В і д н о с н і ~ п р и р о с т и ~}$

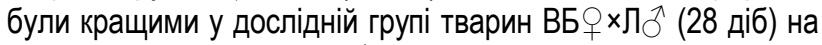
$0,11 \%$ відносно Ло ×ВБぇ (28 діб), на $14,12 \%$ ( $<<0,001)-$

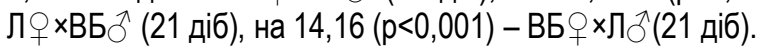

За комплексною оцінкою відтворювальних якостей між групами тварин не виявлено суттєвої відмінності за даним показником, різниця знаходилася в проміжку 0,08 0,3 бала.

У процесі дослідження відтворювальних якостей свиноматок ми дійшли висновку, що найкращий показник багатоплідності (рис. 1) мали тварини 3 варіантом поєднання порід ЛохВБЈ зі скороченим терміном підсисного періоду. Даний показник вищий за породне поєднання ВБОхЛ $\widehat{~(28 ~ д і б) ~ н а ~ 0,16 ~ г о л о в и, ~ а б о ~ 1,17 \% ; ~}$

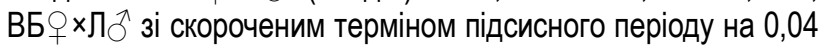
голови, або в 0,29\%; Ло् ×ВБ今 (28 діб) на 0,08 голови $(0,58$ $\%)$. 


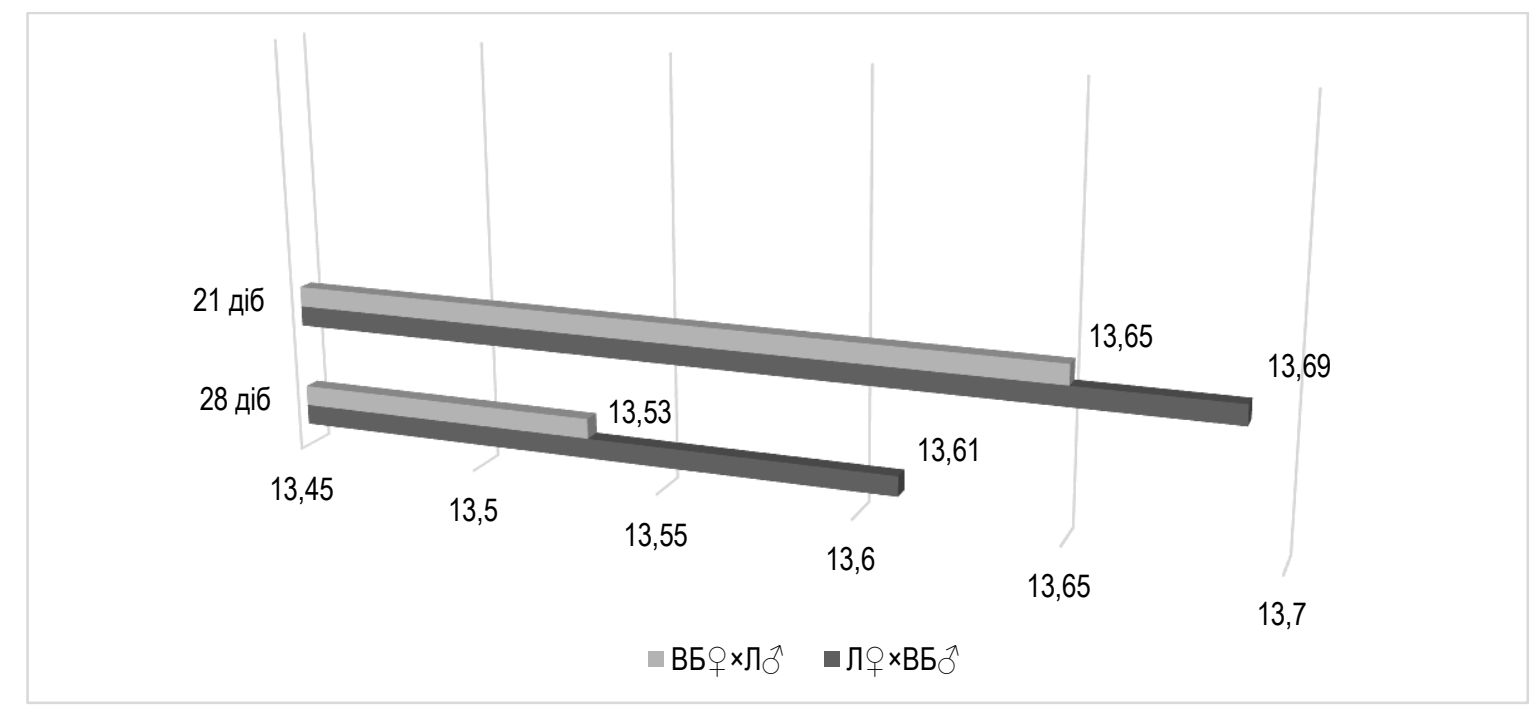

Рис.1. Динаміка показника багатоплідності поросят залежно від варіанту поєднання порід та тривалості підсисного періоду, гол.

Найбільшу кількість поросят відлучали у свиноматок (рис. 2) з варіантом породного поєднання ЛㅜВБ스, зі голови. Дане значення перевищує своїх аналогів на 0,08 \% скороченим терміном підсисного періоду, на рівні 12,67

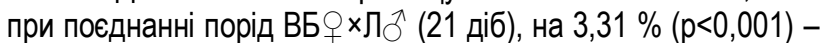

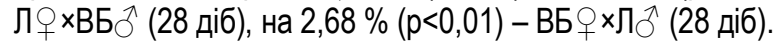

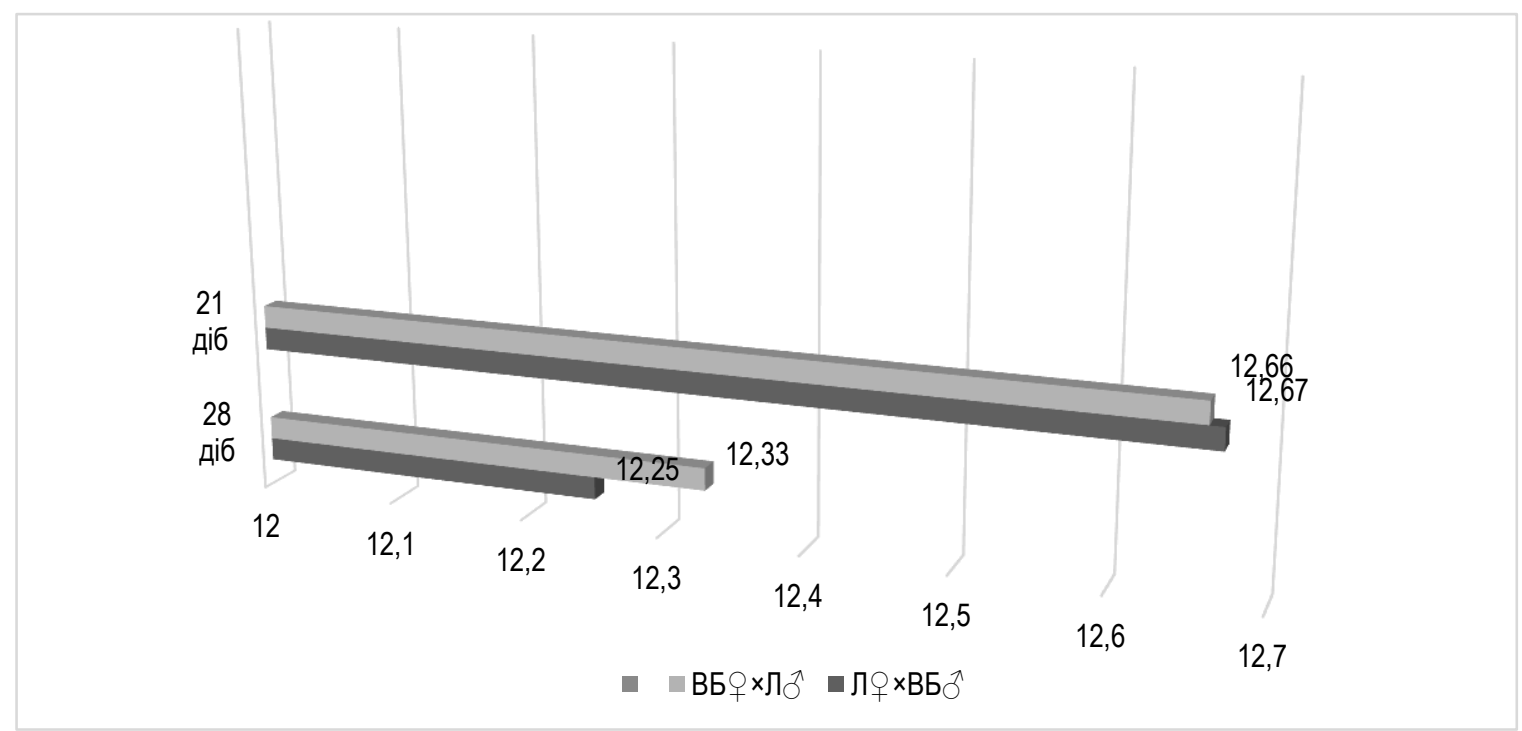

Рис.2. Динаміка кількості поросят при відлученні залежно від варіанта поєднання порід та тривалості підсисного періоду, гол.

Найкраща збереженість спостерігалася у тварин зі

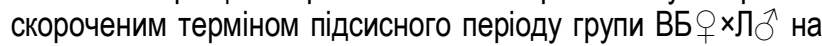
рівні 93,55\%. Тварини з аналогічним терміном підсисного періоду групи ЛохВБАे, мали на 0,03 \% нижчий показник збереженості, Л ×ВББ

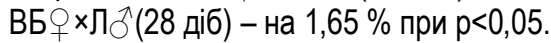




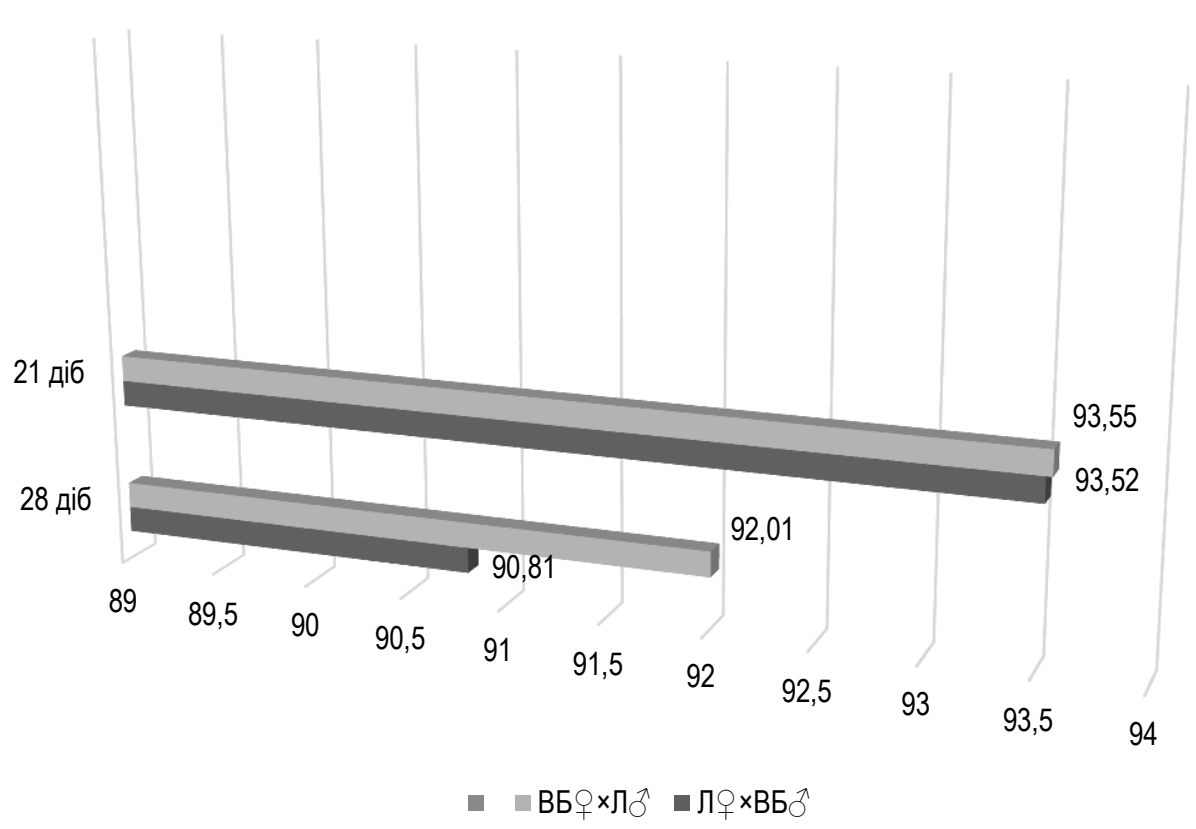

Рис.3. Динаміка збереженості поросят залежно від варіанта поєднання порід та тривалості підсисного періоду, гол.

3 отриманих даних ми дійшли висновку, що на багатоплідність (рис. 4) не впливає варіант поєднання порід свиноматок ( $F$ варіант поєднання порід $0,45<F$ критичне 3,85$)$. Вплив тривалості підсисного періоду виявився статистично

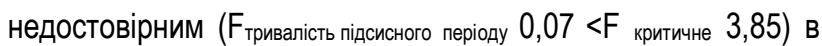
межах 0,08\%. Взаємодія досліджуваних фракторів також становила менше $1 \%$ Сила впливу факторів, що не досліджувалися знаходилася на рівні 99,85\%.

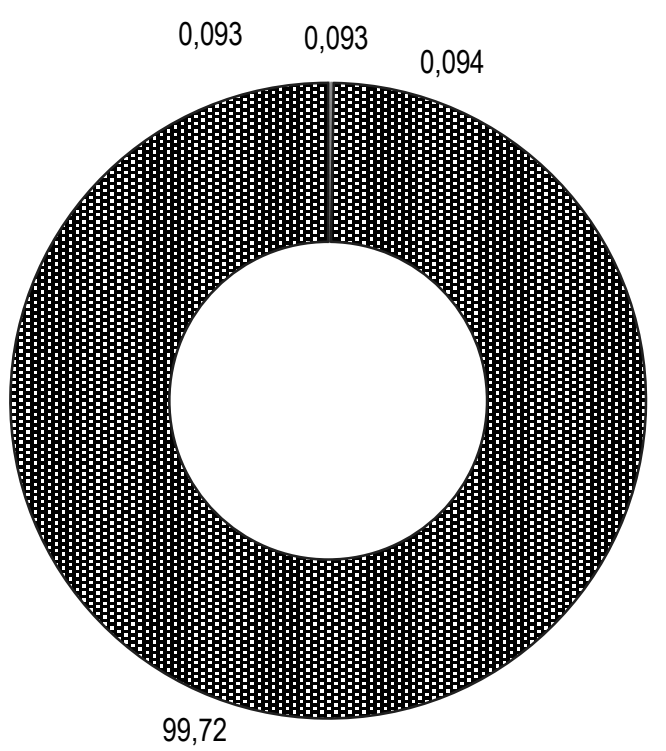

口Варіант паєднення порід

$\square$ Тривалість підсисного періоду

$\square$ Взаємодія факторів

Вплив неврахованих фракторів

Рис. 4. Сила впливу факторів поєднання порід і терміну відлучення поросят на кількість поросят при народженні, \%.

Результати вивчення впливу породних поєднань та тривалості підсисного періоду на кількість поросят на час відлучення (рис. 5) виявилися статистично достовірними

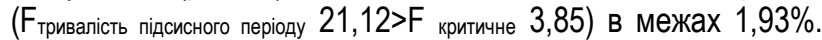
Водночас вплив фактору варіанту поєднання порід був статистично недостовірним ( $F$ варіант повднання порід $0,05<F$ критичне

$3,85)$ і становив $0,04 \%$. Аналогічно попередньому показнику взаємодія досліджуваних факторів не має значної сили впливу на кількість поросят під час відлучення і становить $0,06 \%$. Вплив фракторів не врахованих у дослідженні знаходиться на рівні $97,95 \%$. 


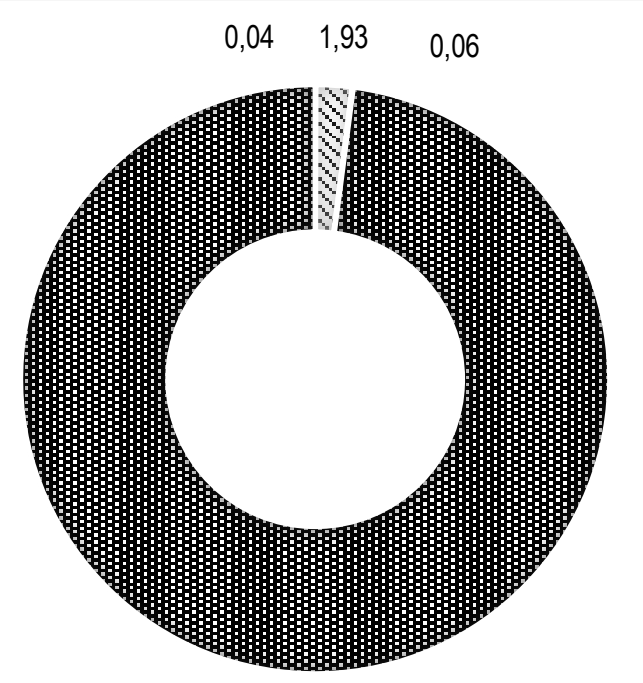

- Варіант паєднення порід

s Тривалість підсисного періоду

- Взаємодія факторів

- Вплив неврахованих факторів

95,97

Рис. 5. Сила впливу факторів варіанту поєднання порід і терміну відлучення поросят на кількість поросят під час відлучення, \%.

У даному дослідженні збереженість поросят (рис. 6) не залежала від варіантів поєднання порід ( $F$ варіант поєднання порід 2,74<F критичне 3,85). Тим не менш вплив тривалості підсисного періоду $€$ статистично достовірним ( $F_{\text {тривалість }}$

підсисного періоду 21,95>F критичне 3,85) і складає 2\%. Взаємодія факторів $€$ статистично не достовірною в межах $0,15 \%$. Не враховані фрактори на рівні $97,58 \%$ діють на показник збереженості.

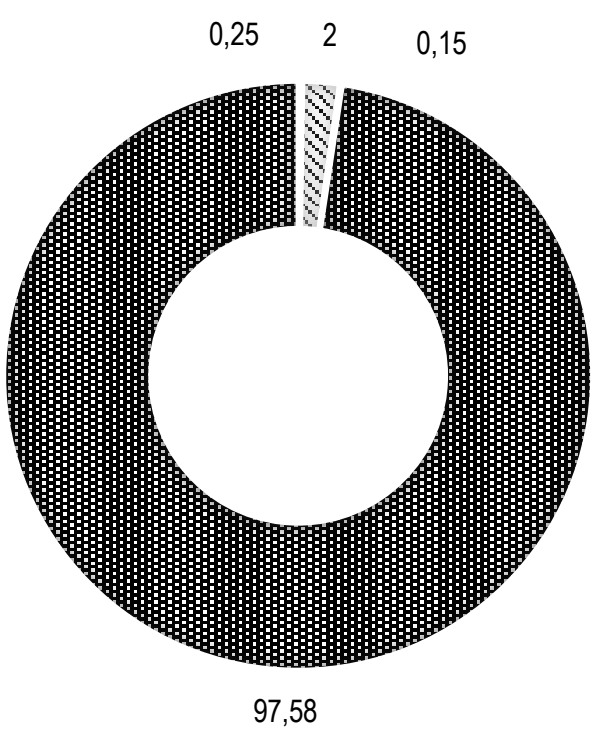

- Варіант паєднення порід

- Тривалість підсисного періоду

- Взаємодія фокторів

- Вплив неврахованих факторів

Рис. 6. Сила впливу факторів варіанту поєднання порід і терміну відлучення поросят на збереженість, \%.

Маса гнізда при відлученні (рис. 7) не залежить від варіанту поєднання порід ( $F$ варіант поєднання порід $1,40<F$ критичне 3,85). При цьому тривалість підсисного періоду достовірно впливає на даний показник ( $F_{\text {тривалість підсисного }}$ періоду 2255,77>F критичне 3,85) і становить 67,81\%. Взаємодія фракторів не містить відчутного впливу на даний показник. Вплив інших факторів знаходиться на рівні $32,10 \%$. 


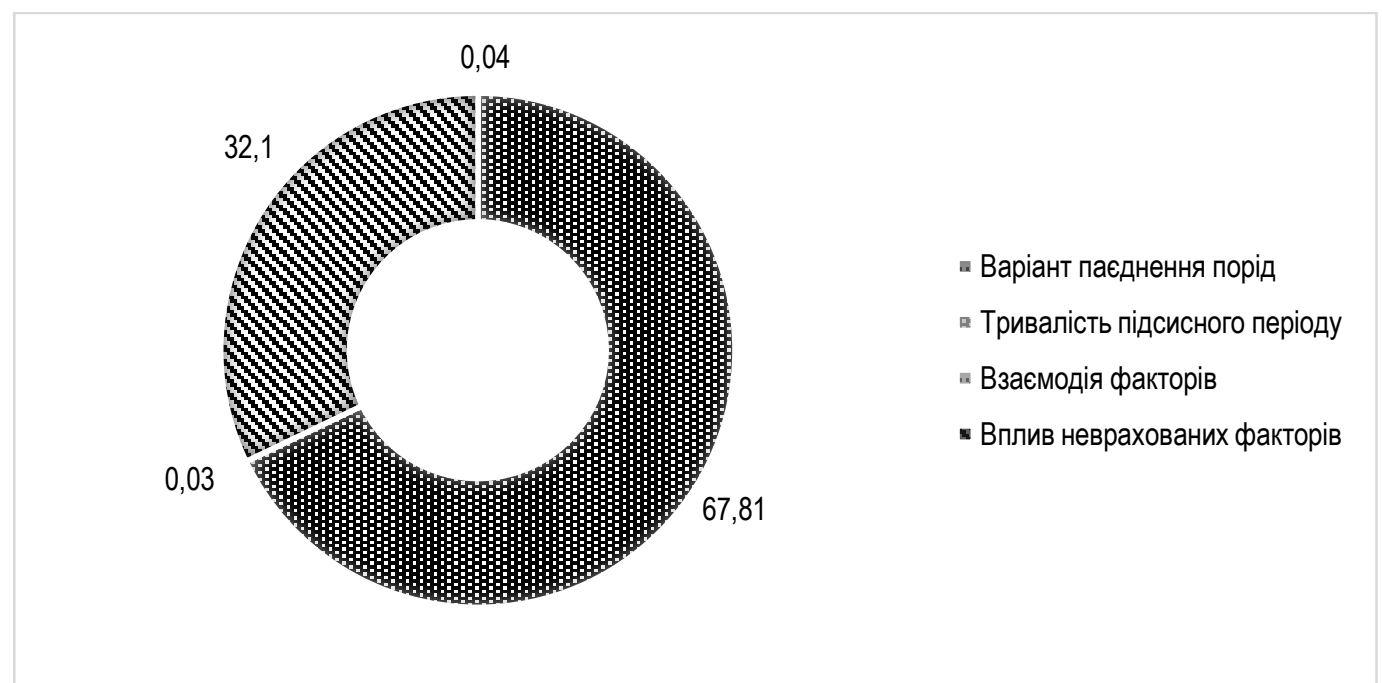

Рис. 7. Сила впливу факторів варіанту поєднання порід і терміну відлучення поросят на масу гнізда поросят при відлученні, \%.

\section{Висновки.}

1.Встановлено, що тривалість підсисного періоду достовірно впливає на масу гнізда при відлученні $\left(\mathrm{F}_{\text {тривалість }}\right.$ пірсисного періоду $2255,77>\mathrm{F}$ критичне 3,85 ) на рівні $67,81 \%$ та на кількість поросят на час відлучення ( $F_{\text {тривалість підсисного періоду }}$

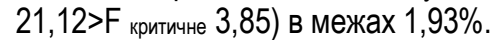

2.Взаємодія фракторів генетичної належності та тривалості підсисного періоду є статистично недостовірними у всіх досліджуваних показниках.

3.Не було встановлено суттєвого впливу варіанту поєднання порід на продуктивні якості свиноматок. 


\section{Список використаної літератури:}

1. Баркарь Є. В., Баркарь Е. В., Дехтяр, Ю. Ф. Використання кнурів-плідників м'ясних порід для покращення показників росту та відгодівельних якостей молодняку свиней. Научный взәляд в будущее. 2017. Вип. 6. Т. 5. С. 16 -20.

2. Березовский Н. Д., Почерняев Ф. К., Коротков В. А. Методика моделирования индексов для использова ния их в селекции свиней. Методы улучшения процессов селекции, разведения и воспроизводства свиней (методические указания). М., 1986. С. $3-14$.

3. Березовский, М. Д., Попова, В. М., Цирик, К. О., Огуренко, В. С. Відтворювальні якості свиноматок в системі гібридизації. Свинарство. 2012. № 60. С. 21-24. C. 23-25.

4. Близнецов А. В. Результативность скрещивания свиней при разных типах кормления. Зоотехния. 2002. № 8.

5. Войтенко С., Шаферівський Б. Генотип свиней і його вплив на відгодівельні ознаки. Вісник Сумського національного аграрного університету. Серія: Тваринництво, 2013. Вип. 1 (22). С. 26 -28.

6. Глотова Л. Н., Архипова Е. Н. Продуктивные показатели свиней при гибридизации. Материалы Всероссийской (национальной) научно - практической конференции, посвященной 100 -летию со дня рождения профессора А.А. Сысоева. Роль и место инноваций в сфере агропромышленного комплекса. Курск. 2020. С. 201-204.

7. Максимов, А. Г. Генотип и мясная продуктивность свиней. Главный зоотехник, 2014. №10. С. $27-31$.

8. Пелих В. Г. Ушакова С. В. Динаміка росту молодняку свиней різних генотипів. Науково -технічний бюлетень інституту тваринниитва НААН. 2016. № 115. С. 169-175.

9. Петренко М. О., Войтенко С. Л. Свині породи ландрас за чистопородного розведення та схрещування. Науковий вісник ЛНУВМБТ імені С.3. Ґжицького. Миколаїв, 2011. Т. 13. № 4 (50) Ч. 3. С. 146-149.

10. Повод М. Г., Храмкова, О. М. Відтворювальні якості свиноматок $F_{1}$ різної селекції та інтенсивність росту їх приплоду при гібридизації в умовах промислового комплексу. Науково -технічний бюлетень інституту тваринництва НАAН. 2016. № 116. С. $121-126$.

11. Соляник В. В. О прибыльности производства свинины в товарных хазяйствах. Повышение интенсификации и конкурентоспособности отраслей животноводства: междунар. науч. - практ. конф., 14 - 15 сентября 2011. Жодино, 2011. 4 24. С. $344-347$.

12. Стрижак Т. А. Відтворювальні якості свиноматок при їх схрещуванні з кнурами різних генотипів. Науково технічний бюлетень інституту тваринництва НААН. 2015. № 114. С. 155-161.

13. Федоренкова, Л.А. и др. Эффрективность использования хряков специализированных мясных пород при скрещивании со свиноматками крупной белой и белорусской мясной пород. Сб. науч. тр. «Зоотехническая наука Беларуси». 2011. Т. 46. Ч. 1. С. 192-199.

14. Jarvis S., et al. Effects of weaning age on the behavioural and neuroendocrine development of piglets. Applied Animal Behaviour Science. 2008. Issue 1. P. 166-181.

15. Pluske J., Payne H., Williams I. H., Mullan Br. Early feeding for lifetime performance of pigs. Recent Advances in Animal Nutrition in Australia. 2005. Issue 15. P. 171-181.

16.

References:

1. Barkar,' Je.V., Barkar', E.V. and Dehtjar, Ju.F., 2017. Vykorystannja knuriv -plidnykiv m'jasnyh porid dlja pokrashhennja pokaznykiv rostu ta vidgodivel'nyh jakostej [Use of breeding boars of meat breeds to improve the growth and fattening qualities of young pigs]. Nauchnyj vzgljad v budushhee, vol 6, issue 5, pp. 16-20.

2. Berezovskiy, N.D., Pochernyaev, F.K., Korotkov, V.A., 1986. Metodika modelirovaniya indeksov dlya ispolzovaniya in v selektsii sviney [Methodology for modeling indices for use in breeding pigs]. Metodyi uluchsheniya protsessov selektsii, razvedeniya i vosproizvodstva sviney (metodicheskie ukazaniya) pp. 3-14.

3. Berezovskyj, M.D., Popova, V.M., Cyryk, K.O., Ogurenko, V.S., 2012. Vidtvorjuval'ni jakosti svynomatok v systemi gibrydyzacii' [Production of sows in the system of hybridization]. Svynarstvo, issue 60, pp. 21-24.

4. Bliznecov, A.V., 202 Rezul'tativnost' skreshhivanija svinej pri raznyh tipah kormlenija [The effectiveness of crossing pigs with different types of feeding]. Zootehnija, issue 8, pp. 23-25.

5. Vojtenko, S., Shaferivs'kyj, B., 2013. Genotyp svynej i jogo vplyv na vidgodivel'ni oznaky [Genotype of pigs and its influence on fattening traits]. Visnyk Sumskoho NAU. Seriia «Tvarynnytstvo», issue 1 (22), pp. 26-28.

6. Glotova, L.N., Arhipova, E.N., 2020. Produktivnye pokazateli svinej pri gibridizacii. [Performance indicators of pigs during hybridization]. Materialy Vserossijskoj (nacional'noj) nauchno -prakticheskoj konferencii, posvjashhennoj 100 - letiju so dnja rozhdenija professora A.A. Sysoeva Rol' i mesto innovacij v sfere agropromyshlennogo kompleksa, Kursk, pp. 201-204.

7. Maksimov, A.G., 2014. Genotip i mjasnaja produktivnost' svinej [Pig genotype and meat productivity]. Glavnyj zootehnik, issue 10, pp. 27-31.

8. Pelyh, V.G., Ushakova, S.V., 2016. Dynamika rostu molodnjaku svynej riznyh genotypiv [Dynamics of growth of young pigs of different genotypes]. Naukovo - tehnichnyj bjuleten' IT NAAN-NNo115. Instytut tvarynnyctva NAAN, pp. 169-175.

9. Petrenko, M.O., Vojtenko, S.L., 2011. Svyni porody landras za chystoporodnogo rozvedennja ta shreshhuvannja [Landrace pigs for purebred breeding and crossbreeding]. Naukovyj visnyk LNUVMBT imeni S.Z. G'zhyc'kogo. vol. 13, issue. 4 (50), pp. 146-149.

10. Povod, M.G., Hramkova, O.M., 2016. Vidtvorjuval'ni jakosti svynomatok $F_{1}$ riznoi' selekcii' ta intensyvnist' rostu i'h pryplodu pry gibrydyzacii' $v$ umovah promyslovogo kompleksu [Reproductive qualities of $F_{1}$ sows of different selection and 
growth intensity of their offspring during hybridization in the conditions of an industrial complex]. Naukovo -tehnichnyj bjuleten' IT NAAN-№115. Instytut tvarynnyctva NAAN, pp. 121-126.

11. Soljanik, V.V., 2011., O pribyl'nosti proizvodstva svininy v tovarnyh hazjajstvah [On the profitability of pork production in commercial farms]. Mat. mizhd studen nauk. prakt. konferencii, Zhodino, pp. 344-347.

12. Ctryzhak, T.A., 2015. Vidtvorjuval'ni jakosti svynomatok pry i'h shreshhuvanni z knuramy riznyh genotypiv [Reproductive qualities of sows when crossing them with boars of different genotypes]. Naukovo - tehnichnyj bjuleten' IT NAAN№. Instytut tvarynnyctva NAAN, pp. 155-161.

13. Fedorenkova, L.A. i dr.,2011. Jeffektivnost' ispol'zovanija hrjakov specializirovannyh mjasnyh porod pri skreshhivanii so svinomatkami krupnoj beloj i belorusskoj mjasnoj porod [Efficiency of using boars of specialized meat breeds when crossing with sows of large white and Belarusian meat breeds]. Sb. nauch. tr. "Zootehnicheskaja nauka Belarusi», vol 146, issue 1, pp. 192-199.

14. Jarvis, S., et al., 2008. Effects of weaning age on the behavioural and neuroendocrine development of piglets. Applied Animal Behaviour Science, issue 1, pp. 166-181.

15. Pluske, J., Payne, H., Williams, I.H. and Mullan, Br., 2005. Early feeding for lifetime performance of pigs. Recent Advances in Animal Nutrition in Australia, issue 15, pp. 171-181.

\author{
Shvachka Ruslan Petrovich, postgraduate \\ Povod Nikolai Grigorovich, Doctor of Agricultural Sciences, Professor \\ Sumy National Agrarian University
}

Influence of the factors of the variant of combination of breeds and duration of the lactation period on reproductive qualities of sows

In the conditions of the commodity enterprise the influence of variants of breed combinations of sows and duration of the lactation period on their reproductive qualities was investigated 2 technological groups of sows with the usual (28 days) and shortened (21 days) lactation period were formed. Each of the obtained groups was divided according to genetic affiliation into

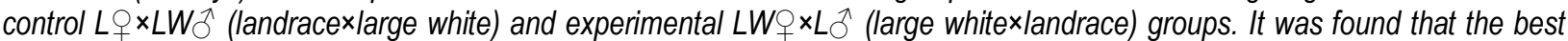
rate of fertility was observed in animals with a variant of the breed combination $L Q \times L W \widehat{O}$ with a reduced duration of the suckling

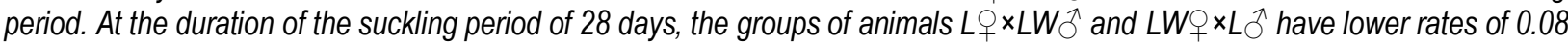
and 0.16 heads, respectively. The ratio of sexes in all studied groups was practically at the same level with fluctuations towards boars in the range of $50.33 \%-50.84 \%$. The largest nest weight at birth was observed in animals of the group $L+9 \times L W \widehat{O}(28$ days) with an excess of this indicator in the range of $0.69-1.17 \%$. The weight of piglets during weaning ranged from 5.42 to 7.73 $\mathrm{kg}$. At the same time the advantage of groups with longer duration of the sucking period is observed. Analyzing the dynamics of the average daily growth of piglets, it was found that the best assimilation of feed was observed in animals of group $L W$ P $\times L^{\lambda}$ (28 days) at the level of $235.05 \mathrm{~g}$, which is $0.29 \%$ less than animals with a combination of breeds $L q \times L W \widehat{O}$ (28 days), by

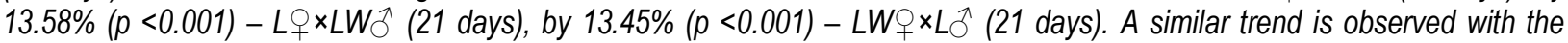
absolute growth rate, where the most important are the animals of the experimental group with the traditional duration of the

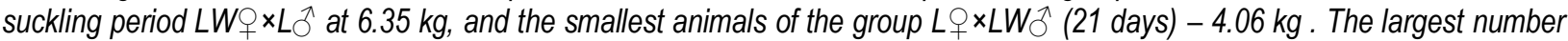
of piglets was weaned in sows with a variant of the breed combination $L$ 우 $\angle W W \widehat{S}$, with a reduced suckling period. The best preservation was observed in animals with a shortened suckling period of the $L W O \times L{ }^{-1}$ group at the level of $93.55 \%$, the rest of the animals had lower values in the range of $0.03-2.93 \%$. From the obtained data, we concluded that the factor of the variant of the combination of breeds does not affect the indicators: the number of piglets at birth, the number of piglets at weaning, safety and nest weight of piglets during weaning. At the same time, a statistically significant effect of the duration of the suckling period on the nest weight of piglets during weaning was found at the level of $67.81 \%$. According to a comprehensive assessment of reproductive qualities between groups of animals, no significant difference was found in this indicator, the difference was in the range of 0.08-0.3 points.

Key words: sow, piglets, lactation period, growth, fertility, safety, combination of breed.

Дата надходження до редакції: 21.01.2020 p. 